\title{
Histiocytic and Dendritic Cell Neoplasm
}

National Cancer Institute

\section{Source}

National Cancer Institute. Histiocytic and Dendritic Cell Neoplasm. NCI Thesaurus. Code C9294.

Rare tumors that affect the hematopoietic and lymphoid tissues. The cells of orig in are the histiocytes and accessory cells. They can occur at any age and show no significant variations in geographical distribution. This category includes the histiocytic sarcoma, Langerhans cell histiocytosis, Langerhans cell sarcoma, interdigitading dendritic cell sarcoma/tumor, follicular dendritic cell sarcoma/tumor, and dendritic cell sarcoma, not otherwise specified. (WHO, 2001) 